\title{
Sita Jaminan Sebagai Upaya Menjamin Terlaksananya Putusan Perkara Perdata
}

\author{
Joejoen Tjahjani $\left.{ }^{*}\right)$ \\ *) Dosen Fakultas Hukum Universitas Islam Lamongan
}

\begin{abstract}
ABSTRAK
Penelitian tentang sita jaminan yang dapat menjamin terlaksananya keputusan perkara perdata yang telah mempunyai kekuatan hukum tetap menarik untuk dikaji lebih lanjut. Hal ini untuk mengetahui apakah sita jaminan dapat menjamin terlaksananya keputusan perkara perdata yang telah mempunyai kekuatan hukum tetap. Di samping itu, juga untuk mengetahui kendalakendala yang ditemui dalam praktek berkenaan pelaksanaan sita jaminan.

Metode yang dipakai dalam penelitian menggunakan pendekatan yuridis normatif. Sumber datanya berasal dari data primer maupun sekunder. Sedangkan analisis datanya menggunakan analisis deskriptif kualitatif.

Dari hasil penelitian dapat disimpulkan bahwa timbulnya permintaan pelaksanaan sita jaminan bermula dari adanya dugaan yang beralasan dari pihak penggugat bahwa seseorang yang berhutang sebelum dijatuhkan putusan atau sebelum putusan yang mengalahkannya dapat dijalankan, berdaya upaya akan menghilangkan atau membawa barangnya yang bergerak maupun yang tidak bergerak dengan maksud menjauhkan barang-barang tersebut dari pihak penagih hutang atau penggugat. Adapun yang jadi kendala-kendala yang ditemui dalam praktek berkenaan pelaksanaan sita jaminan adalah disebabkan karena barang-barang yang telah disita pada waktu akan dilaksanakan sudah tidak ada lagi atau sudah rusak, atau telah ada perlawanan dari pihak ketiga yang ternyata adalah pemilik sah dari pada barang yang disita atau karena barang-barang yang disita tersebut diagunkan di Bank.
\end{abstract}

\section{Kata Kunci : Sita Jaminan, Putusan Perkara Perdata}

\section{Pendahuluan}

Semua alat perlengkapan negara dalam menjalankan tugas dan kewajibannya selalu mendasarkan diri pada aturan-aturan hukum yang berlaku. Hal ini menunjukkan bahwa Negara Republik Indonesia merupakan negara hukum, sesuai dengan apa yang telah disebutkan dalam penjelasan Undang-undang Dasar 1945, bahwa "Negara Indonesia berdasarkan atas hukum (Recht Staat) tidak berdasar atas kekuasaan belaka (Machts Staat) (lihat penjelasan Undangundang Dasar 1945).

. Setiap anggota masyarakat wajib mentaati hukum, ia tidak dapat bertindak sewenangwenang, ia harus mengatur perjalanan hidupnya sehari-hari menurut garis-garis tertentu sesuai dengan peraturan-peraturan yang berlaku. Tetapi ditengah-tengah masyarakat secara disadari atau tidak selalu terjadi pelbagai macam bentuk penyelewengan, penyalahgunaan, ketidakadilan dan kurang tegaknya hukum sebagai konsekwensinya.

Untuk mewujudkan peradilan yang sesuai dengan harapan masyarakat tadi, diperlukan suatu sikap yang baik dari para penegak hukum dan dari masyarakat itu sendiri khususnya pihak pencari keadilan untuk melakukan tugas dan kewajibannya sesuai dengan ketentuan-ketentuan hukum yang berlaku, dengan menjunjung tinggi hak asasi manusia dan mengindahkan asas-asas hukum dalam suatu negara hukum. Selain itu pelaksanaan peradilan yang baik juga tergantung pada pengaturan undang-undangnya, khususnya membuat secara terperinci tata cara yang harus dipatuhi dalam proses peradilan.

Apabila hal tersebut dapat terlaksana, maka putusan yang dijatuhkan oleh hakim akan dapat dialaksanakn dengan baik oleh pihak-pihak yang membutuhkan pengayoman sehingga sikap main hakim sendiri (eigenrechting) tidak akan terjadi. Salah satu upaya untuk menjamin kepentingan penggugat sealam proses pemeriksaan masih berjalan dan sekiranya gugatan dikabulkan oleh hakim, maka pihak penggugat dapat mengajukan permohonan sita jaminan sebagaimana tersebut dalam pasal 1131 KUH Perdata. Adapun maksud diajukannya sita 
jaminan adalah Segala kebendaan si berutang, baik yang bergerak maupun yang tak bergerak, baik yang sudah ada maupun yang baru akan ada di kemudian hari, menjadi tanggungan untuk segala perikatan perseorangan.

Untuk kepentingan penggugat agar terjamin haknya sekira gugatannya dikabulkan nanti, undang-undang menyediakan upaya untuk menjamin hak tersebut, yaitu dengan penyitaan. Dengan adanya sita jaminan itu, maka tergugat akan kehilangan wewenangnya untuk memindahkan haknya atau harta kekayaannya lagi, dan juga merupakan tindakan untuk menjamin dapat dilaksanakannya putusan perkara perdata yang telah mempunyai kekuatan hukum yang tetap.

Tetapi dalam kenyataannya masalah sita jaminan dalam praktek masih banyak mengalami hambatan-hambatan yang menyebabkan pelaksanaan dan peletakan sita jaminan tidak dapat dilaksanakan dengan sempurna. Hal tersebut disebabkan karena pelaksanaan sitaan tidak sesuai dengan peraturan yang berlaku, sehingga pada waktunya pensitaan tidak dapat dinyatakan syah dan berharga atau oleh karena penyitaan telah tidak dilaksanakan sebagaimana mestinya, missal karena tidak dicatat pada Kantor Pendaftaran Tanah, dalam hal uang disita itu barang yang tidak bergerak yang telah terdaftar sehingga apabila barang tersebut selama proses pemeriksaan perkara berlangsung dijual tergugat.

Sebaliknya tidak jarang pula dari pihak debitur atau tergugat yang tidak beriktikat baik mengajukan keberatannya atas penyitaan yang telah dilakukan dengan memutarbalikkan fakta yang sebenarnya, yang kadang kala tidak dikemukakan dimuka persidangan, melainkan justru mengadukan kepada Pengadilan Tinggi atau ke Mahkamah Agung bahwa Pengadilan Negeri telah melakukan tindakan yang melawan hukum dan bertentangan dengan hak asasi manusia.

\section{Kajian Teori}

Sita jaminan sebagai istilah yuridis belum ada terjemahan resminya dalam bahasa Indonesia, karena dalam beberapa peraturan perundang-undangan Indonesia belum ada istilah yang sesuai dengan sita jaminan. Hal ini dapat dilihat dalam praktek bahwa para sarjana ahli hukum menggunakan istilah yang berbeda-beda diantaranya.

Sudikno Mertokusumo, dalam bukunya Hukum Acara Perdata Indonesia dan Ny. Retnowulan dalam bukunya Hukum Acara Perdata Dalam Teori dan Praktek, menggunakan istilah "Sita Jaminan". Sementara itu, Wirjono Projodikoro, dalam bukunya Hukum Acara Perdata di Indonesia, menggunakan istilah "Penyitaan untuk Menyimpan". R. Trisna, dalam bukunya Komentar atas Reglemen Hukum Acara Di dalam Pemeriksaan di muka Pengadilan Negeri, langsung menyebut istilah "Sita Jaminan". Abdul Kadir Muhammad, dalam bukunya Hukum Acara Perdata Indonesia menggunakan istilah "Sita Jaminan", dan John Z. Loudue, dalam bukunya Beberapa Aspek Hukum Materiil dan Hukum Acara dalam Praktek, serta Ateng Afandi, Wahyu Afandi, dalam bukunya Tentang Melaksanakan Putusan Hakim Perdata, menggunakan istilah "Sita Jaminan".

Berdasarkan arti katanya, Sita Jaminan adalah berasal dari kata "sita" yang artinya untuk menyimpan, dan kata "jaminan" yang artinya hak, jadi sita jaminan menurut arti katanya dapat diartikan hak untuk menyimpan.

Menurut Ny. Retnowulan Sutantio dan Iskandar Oerip Kartawinata, sita jaminan diartikan sebagai "untuk menjamin pelaksanaan suatu keputusan dikemudian hari, barangbarang milik tergugat baik yang bergerak maupun yang tidak bergerak selama proses berlangsung barang-barang tersebut tidak dapat dialihkan, diperjual belikan atau dengan jalan dipindahtangankan kepada orang lain.

Sedangkan Sudikno Mertokusumo, memberikan pengertian sita jaminan yang beliau terjemahkan dalam istilah "sita jaminan" diartikan sebagai "barang-barang yang disita untuk kepentingan penggugat (kreditur) dibekukan, ini berarti bahwa barang-barang itu boleh disimpan (diconserveer) untuk jaminan dan tidak boleh dialihkan atau dijual.

Menurut Abdulkadir Muhammad, sita jaminan diartikan "sebagai sita yang dapat dilakukan oleh pengadilan atas permohonan penggugat untuk mengamankan barang yang sedang disengketakan supaya tidak dirusak, dihilangkan, dipindahtangankan sebelum perkara berakhir. 
Kemudian Subekti, mengartikan sita jaminan sebagai "penyitaan barang-barang milik debitur untuk pengaman sementara sebagai jaminan akan hak-hak kreditur yang sedang atau segera diperjuangkan dimuka pengadilan.

Dari beberapa pendapat para sarjana dalam mengartikan sita jaminan, penulis dapat menyimpulkan bahwa pada dasarnya pendapat tersebut adalah sama yaitu sama-sama menjamin untuk kepentingan kreditur (penggugat), tetapi hanya ada sedikit perbedaan dimana pengertian sita jaminan menurut Sudikno Mertokusumo, tidak membedakan barang yang disita itu milik kreditur (penggugat) atau milik debitur (tergugat), sedangkan dalam pengertian sita jaminan menurut Subekti, yang dapat disita itu hanya terhadap barang-barang atau harta benda milik debitur saja.

Sita jaminan" menurut pasal 1132 KUH Perdata adalah suatu tindakan hukum yang dilakukan oleh juru sita atau panitera Pengadilan Negeri atas perintah Ketua Pengadilan Negeri untuk menyita barang-barang bergerak maupun barang tidak bergerak milik debitur/tergugat, karena adanya dugaan yang beralasan bahwa debitur atau tergugat akan mengalihkan atau menggelapkan barang-barang miliknya untuk menghindari penyitaan, dan penyitaan itu dilakukan atas permohonan pihak yang berkepentingan.

Yang dimaksud dengan obyek dari pada sita jaminan menurut pasal 1131 KUH Perdata adalah barang yang dapat dikenai atau dibebani sita jaminan. Yang dapat dijadikan obyek sita jaminan adalah semua harta milik seseorang, baik yang berupa barang bergerak maupun barang tidak bergerak, baik yang sudah ada maupun yang baru akan ada dikemudian hari, dapat dijadikan obyek sita jaminan.

Tetapi diluar dari pasal 1131 KUH Perdata tersebut, dikecualikan terhadap barangbarang tertentu yang tidak dapat dikenai atau dibebani sita jaminan, yaitu :

a. Terhadap barang dan perkakas yang benar-benar oleh si tersita dipergunakan untuk mencari nafkah.

b. Terhadap hak yang bersifat pribadi, yaitu hak pakai dan hak mendiami (pasal 825, $827 \mathrm{KUH}$ Perdata).

c. Terhadap hak untuk mendapatkan ganti kerugian dalam hubungan perburuhan.

d. Terhadap harta pusaka yang merupakan milik family sebagai persekutuan hukum.

Mengenai harta pusaka yang terhadapnya tidak dapat dipakai/dibebani sita jaminan, mengatakan Subekti bahwa bagi daerah-daerah luar Jawa dan Madura, yang dikuasai oleh Rechtsreglement Buitengewesten atau Reglement Daerah Seberang (RDS) disebutkan bahwa bagi daerah Bengkulu, Minangkabau dan Tapanuli, barang-barang harta pusaka hanya boleh disita apabila harta pencaharian pihak yang dikalahkan tidak mencukupi untuk memenuhi keputusan.

Ketentuan ini tepat, karena menurut hukum adat Minangkabau tidak boleh dilakukan eksekusi menyangkut hutang seorang pribadi atas harta pusaka family, seorang pribadi tidak dianggap sebagai bagian dalam harta pusaka familinya itu, harta pusaka adalah milik family sebagai persekutuan hukum.

\section{A. Pihak-Pihak Dalam Perkara Perdata}

Di dalam suatu sengketa perdata, sekurang-kurangnya terdapat dua pihak, yaitu pihak penggugat (eiser, plaintiff) yang mengajukan gugatan, dan pihak tergugat (gedaagde, defendant). Biasanya orang yang langsung berkepentingan sendirilah yang aktif bertindak sebagai pihak di muka pengadilan, baik sebagai penggugat maupun sebagai tergugat. Mereka ini merupakan pihak materiil, karena mereka mempunyai kepentingan langsung di dalam perkara yang bersangkutan, tetapi sekaligus juga merupakan pihak formil. Karena merekalah yang beracara di muka pengadilan. Mereka bertindak untuk kepentingan dan atas namanya sendiri.

Akan tetapi seorang dapat pula bertindak sebagai penggugat atau tergugat di muka pengadilan tanpa mempunyai kepentingan secara langsung dalam perkara yang bersangkutan. Seorang wali atau pengampu bertindak sebagai pihak di muka pengadilan atas namanya sendiri, tetapi untuk kepentingan orang lain yang diwakilinya, karena yang terakhir inilah yang mempunyai kepentingan secara langsung (pasal 383, 446, 452, 403-405 BW). Nama mereka harus dimuat dalam gugatan dan disebut pula dalam putusan, di samping nama-nama yang mereka wakili. Mereka ini merupakan pihak formil, sedangkan yang diwakilinya adalah pihak meteriil. 
Di samping itu, tidak jarang terjadi suatu pihak materiil memerlukan seorang wakil untuk beracara di muka pengadilan, karena tidak mungkin beracara tanpa diwakili. Hal ini terjadi pada badan hukum, yang beracara atas namanya sendiri, tetapi memerlukan seorang wakil yang bertindak di muka pengadilan selaku pihak formil untuk kepentingannya (pasal 8 no. $20 \mathrm{Rv}, 1955 \mathrm{BW}$ ).

Hal tersebut di atas harus dibedakan dari seorang pengacara atau pokrol yang walaupun bertindak atas nama dan kepentingan kliennya, bukanlah merupakan pihak, baik formil maupun materiil. Pada azasnya setiap orang yang merasa mempunyai hak dan ingin menuntutnya atau ingin mempertahankan atau membelanya, berwenang untuk bertindak selaku pihak, baik selaku penggugat maupun selaku tergugat (legitima persona standi in judicio).

Kemampuan untuk bertindak (handelingsbekwaamheid) sebagai pihak itu merupakan komplemen penting dari pada kewenangan hukum (rechtsbevoegdheid) atau kewenangan untuk menjadi pendukung hak. Siapa yang dianggap tidak mampu untuk bertindak (personae miserabiles) dianggap tidak mampu pula untuk bertindak selaku pihak di muka pengadilan. Yang dianggap tidak mampu bertindak sebagai pihak atau tidak mempunyai kemampuan prosesuil, pertama adalah mereka yang belum cukup umur. Mereka diwakili oleh walinya.

Pada umumnya mereka yang diletakkan di bawah pengampuan tidak dapat beracara dan bertindak sebagai pihak di muka pengadilan (Pasal 446, 452 BW, 248 no. 2 Rv), khususnya bagi mereka yang diletakkan di bawah pengampuan karena sakit ingatan. Sedangkan bagi para pemboros dan pemabuk ketidakmampuan ini hanya terbatas pada perbuatan-perbuatan dalam bidang hukum harta kekayaan saja.

Terhadap orang yang telah meninggal dunia dapat pula dilakukan gugatan yang ditujukan kepada seluruh ahli warisnya sekaligus (Pasal 248 no.1 Rv, 1194 BW). Tentang hal ini ada putusan Mahkamah Agung yang menentukan bahwa gugatan terhadap almarhum tergugat asal dianggap diteruskan terhadap para ahli warisnya, bilamana pihak penggugat tidak menaruh keberatan terhadap kemauan para ahli waris almarhum untuk meneruskan perkara dari almarhum tergugat asal. Jadi kedudukan sebagai pihak dapat diwariskan.

Gugatan terhadap badan hukum publik dialamatkan kepada pimpinannya (pasal 6 no. 3 Rv). Kalau gugatan itu ditujukan kepada Negara, maka orang yang mewakilinya tidak perlu disebut namanya di dalam gugatan. Beberapa peraturan perundang-undangan menunjuk dengan tegas siapa-siapa yang ditugaskan untuk mewakili badan hukum publik itu. Pasal 6 no. 1 Rv misalnya menentukan bahwa gugatan terhadap Pemerintah Indonesia harus ditujukan kepada pimpinan Departemen yang bersangkutan.

Terhadap badan hukum lainnya, yaitu badan hukum keperdataan, gugatan ditujukan kepada pengurus dan apabila badan hukum itu telah dibubarkan, kepada salah seorang pemberesnya.

Walaupun Firma bukan badan hukum, namun dapat pula bertindak sebagai pihak, yaitu seluruh persero bersama-sama merupakan satu pihak atau gugatan ditujukan kepada salah seorang persero (pasal 6 no. 5 Rv).

\section{B. Tuntutan Hak}

Tuntutan hak sebagaimana telah diterangkan di muka adalah tindakan yang bertujuan memperoleh perlindungan hak yang diberikan oleh pengadilan untuk mencegah "eigenrichting". Orang yang mengajukan tuntutan hak memerlukan atau berkepentingan akan perlindungan hukum. Ia mempunyai kepentingan untuk memperoleh perlindungan hukum, maka oleh karena itu ia mengajukan tuntutan hak ke pengadilan. Kiranya sudah selayaknya apabila disyaratkan adanya kepentingan untuk mengajukan tuntutan hak. Seseorang yang tidak menderita kerugian mengajukan tuntutan hak, tidak mempunyai kepentingan. Sudah wajar kalau tuntutannya itu tidak diterima oleh pengadilan. Akan tetapi tidak setiap kepentingan dapat diterima sebagai dasar pengajuan tuntutan hak. Bahwa suatu tuntutan hak harus mempunyai kepentingan hukum yang cukup, merupakan syarat utama untuk dapat diterimanya tuntutan hak itu oleh pengadilan. Ini tidak berarti bahwa tuntutan hak yang ada kepentingan hukumnya pasti dikabulkan oleh pengadilan. Hal itu masih tergantung pada pembuktian. Baru kalau tuntutan hak itu terbukti didasarkan atas suatu hak, pasti akan dikabulkan. Mahkamah Agung dalam 
putusannya tanggal 7 Juli 1971 no. 294 K/Sip/1971 mensyaratkan bahwa gugatan harus diajukan oleh orang yang mempunyai hubungan hukum.

Tuntutan hak yang di dalam pasal 142 ayat $1 \mathrm{Rbg}$ disebut sebagai tuntutan perdata (burgerlijke vordering) tidak lain adalah tuntutan hak yang mengandung sengketa dan lazimnya disebut gugatan. Gugatan dapat diajukan baik secara tertulis (pasal 142 ayat $1 \mathrm{Rbg}$ ) maupun secara lisan (pasal 144 ayat $1 \mathrm{Rbg}$ ).

Persyaratan mengenai isi gugatan dijumpai dalam pasal 8 no. $3 \mathrm{Rv}$, yang mengharuskan gugatan pada pokoknya memuat : (1) identitas dari para pihak, (2) dalil-dalil konkrit tentang adanya hubungan hukum yang merupakan dasar serta alasan-alasan dari pada tuntutan (middelen van den eis) atau lebih dikenal dengan fundamentum petendi dan (3) tuntutan (onderwerp van den eis met een duideliljke en bepaalde conclusie) atau petitum.

\section{Upaya-Upaya Untuk Menjamin Hak}

Penyitaan dilakukan oleh Panitera Pengadilan Negeri, yang wajib membuat berita acara tentang pekerjaannya itu serta memberitahukan isinya kepada tersita kalau ia hadir. Dalam melakukan pekerjaannya itu panitera dibantu oleh dua orang saksi yang ikut serta menandatangani berita acara (pasal 209 ayat 1 dan 4, 210 Rbg).

Kalau permohonan sita jaminan itu dikabulkan maka lalu dinyatakan sah dan berharga (van waarde erklaard) dalam putusan, sesudah makna penyitaan itu mempunyai titel eksekutorial, sehingga dapat dilaksanakan.

Sita jaminan ini tidak meliputi seluruh harta kekayaan dari pada debitur atau tergugat, tetapi hanya beberapa barang tertentu saja yang dilakukan oleh seorang kreditur.

\section{Macam-Macam Sitaan Dalam Acara Perdata}

Dalam hokum acara perdata terdapat bermacam-macam sitaan yang terdiri dari :

1. Sita Jaminan Terhadap Barang Miliknya Sendiri.

a. Sita Revindicatoir

Pemilik barang bergerak yang barangnya berada ditangan orang lain dapat diminta, baik secara lisan maupun tertulis kepada ketua Pengadilan Negeri ditempat orang yang memegang barang tersebut tinggal, agar baranng tersebut disita.

b. Sita Maritaal

Sita maritaal bukanlah untuk menjamin suatu tagihan utang atau penyerahan barang, melainkan menjamin agar barang yang disita tidak dijual. Jadi fungsi sita maritaal adalah untuk melindungi hak selama pemeriksaaan sengketa perceraian di Pengadilan berlangsung antara pemohon dan lawannya, dengan menyimpan atau membekukan barang-barang yang disita agar jangan sampai jatuh ditangan pihak ketiga.

\section{Sita Jaminan Terhadap Barang Milik Debitur}

Penyitaan inilah yang biasanya disebut dengan sita jaminan. Sita jaminan ini adalah merupakan tindakan persiapan dari pihak penggugat dalam bentuk permohonan kepada Ketua Pengadilan Negeri untuk menjamin dapat dilaksanakannya putusan perdata dengan menguangkan atau menjual barang debitur yang disita guna memenuhi tuntutan penggugat.

Terjadinya penyitaan ini adalah berdasarkan perintah ketua Pengadilan Negeri atas permintaan kreditur atau penggugat (pasal $1131 \mathrm{KUH}$ Perdata).

Karena sita jaminan itu fungsinya tidak semata-mata untuk menyimpan barang yang disita, tetapi kemudian untuk dijual, maka sita jaminan apabila dikabulkan perlu memperoleh titel eksekutorial, sehingga perlu dinyatakan sah dan berharga didalam putusan (pasal 1131, dan pasal 1132 KUH Perdata), sedangkan apabila ditolak, maka sita jaminan yang telah dijalankan atas perintah hakim dinyatakan dicabut atau diangkat didalam putusan, maka pernyatan sah dan berharga itu dicantumkan dalam dictum putusan Pengadilan Negeri.

Adapun barang yang dapat disita secara jaminan adalah sebagai berikut : 
a. Sita jaminan atas barang bergerak milik debitur (pasal 1131 jo. 1132 KUH Perdata)

b. Sita jaminan atas barang tetap milik debitur (pasal 261, 208, 214 RBG)

c. Sita jaminan atas barang bergerak milik debitur yang ada ditangan pihak ketiga (pasal 728 $\mathrm{Rv}, 211 \mathrm{Rbg}$ )

\section{Pembahasan}

\section{A. Pelaksanaan Sita Jaminan Terhadap Keputusan Perkara Perdata Yang Mempunyai Kekuatan Hukum Yang Tetap}

Dalam prakteknya, permohonan diajukan kepada ketua Pengadilan Negeri yang dilakukan secara tertulis, baik bersamaan dengan surat gugatan perkara pokoknya maupun dilakukan terpisah dengan perkara pokoknya selama masih dalam proses persidangan dalam tingkat pertama.

Selanjutnya jika penggugat mengajukan permohonan penyitaan bukan pada waktu selama proses persidangan, melainkan setelah adanya putusan yang mengalahkan tergugat dimana terhadap putusan tergugat mengajukan banding, maka berdasarkan hasil penelitian diperoleh keterangan bahwa cara pengajuannya yakni permohonan diajukan dengan surat kepada ketua Pengadilan Negeri setempat yang kemudian disampaikan kepada Hakim Tinggi atau Majelis Pengadilan Tinggi yang tengah memeriksa perkara tersebut.

Dalam hal penyitaan dianggap penting, maka Pengadilan Tinggi dengan sutau penetapan akan memerintahkan kepada Pengadilan Negeri yang bersangkutan untuk melaksanakan sitaan tersebut. Begitu menerima permohonan sita jaminan, maka kepada pihak penggugat dan tergugat diberitahu pula supaya menghadap pada persidangan pertama yang akan datang. Permohonan sita jaminan diajukan kepada ketua Pengadilan Negeri, yang sesuai dengan daerah hukumnya.

Permohonan sita jaminan yang diajukan bersama-sama dengan perkara pokoknya berarti bahwa permohonan tersebut diajukan menjadi satu dalam surat gugatan perkara pokoknya dan biasanya dimuat dalam petitum surat gugatan.

Tetapi ada juga permohonan sita jaminan diajukan menyusul kemudian, setelah gugatan perkara pokoknya diajukan. Hal ini bisa terjadi karena setelah pemeriksaan perkara dimulai, misalnya setelah dua, tiga kali sidang penggugat baru mengetahui bahwa setelah ia mengajukan gugatannya, tergugat berusaha menghilangkan, menggelapkan atau memindahtangankan barang-barang miliknya untuk menghindari penyitaan, sehingga penggugat merasa perlu untuk mengajukan permohonan sita jaminan.

Setelah permohonan sita jaminan diajukan, maka mulailah proses pelaksanaannya yang diawali dengan pemeriksaan permohonan yaitu, pemeriksaan yang menyangkut ada atau tidaknya alasan yang dikemukakan oleh pemohon.

Pemeriksaan permohonan sita jaminan tersebut dilakukan, untuk menghindari penyalahgunaan terhadap tindakan sewenang-wenang dari pemohon (penggugat) yang menyebabkan terjadinya penyitaan yang tidak sesuai dengan fungsi dan tujuan sita jaminan.

Menurut Surat Edaran Mahkamah Agung Nomor 05 Tahun 1975 butir 1-c yang menentukan bahwa agar dalam surat permohonan sita jaminan dan surat ketetapan yang mengabulkan permohonan sita jaminan tersebut harus disebutkan alasan-alasan apa yang menyebabkan sita jaminan yang dimohon dan dikabulkan itu, yang berarti bahwa sebelum dikeluarkan surat ketetapan yang mengabulkan permohonan sita jaminan diadakan penelitian terlebih dahulu tentang ada atau tidaknya alasan yang dikemukakan oleh pemohon (penggugat).

Selanjutnya untuk mengabulkan suatu permohonan sita jaminan, selain adanya alasan yang kuat tentang adanya usaha dari tergugat atau debitur untuk menggelapkan barang-barang, perlu juga dipertimbangkan nilai gugatannya dengan nilai barang-barang yang diminta untuk disita, sedangkan menurut Yurisprudensi Mahkamah Agung tertanggal 15 April 1972 Nomor 1121 K / Sip / 1971, kalau pemohon tidak mempunyai bukti yang kuat akan adanya kekhawatiran bahwa tergugat atau debitur akan mengasingkan barangbarangnya, maka permohonan sita jaminan tidak akan diterima. 
Syarat adanya dugaan ini tidak hanya sekedar dicantumkan begitu saja, akan tetapi merupakan suatu usaha untuk mencegah penyalahgunaan agar tidak diadakan penyitaan secara serampangan, yang akhirnya hanya merupakan tindakan yang sia-sia saja yang tidak mengenai sasaran.

Apabila pemeriksaan permohonan consevatoir beslag dilakukan secara menjalankan pemeriksaan perkara biasa yang cukup lama, maka dimungkinkan permohonan sita jaminan tidak akan membawa hasil. Sehingga dapat dimungkinkan barang-barang yang disita menjadi rusak, kecuali terhadap barang-barang bergerak yang cepat rusak, atau dapat pula memberi peluang kepada debitur atau tergugat untuk mengalihkan sebagian maupun seluruh dari barang-barangnya.

Oleh karena itu, pemeriksaan permohonan sita jaminan sebaiknya dilakukan secara khusus, dimana keputusannya dituangkan dalam surat penetapan yang memuat suatu perintah untuk dilaksanakan.

Jika permohonan sita jaminan diterima, maka hakim yang memeriksa pokok perkaranya akan mengeluarkan surat penetapan jaminan, dan memerintahkan kepada juru sita atau juru sita pengganti untuk melaksanakannya.

Mengenai pelaksana dari pada sita jaminan dilakukan oleh juru sita atau juru sita pengganti Pengadilan Negeri. Dan bila penitera tersebut berhalangan karena pekerjaannya atau oleh sebab lain maka ia digantikan oleh seorang yang cakap atau dapat dipercaya yang ditunjuk oleh ketua.

Segala pekerjaan yang dilakukan, dicatat didalam surat berita acara penyitaan dan isi berita acara tersebut harus diberitahukan kepada orang yang disita barangnya atau tergugat, apabila ia hadir. Berita acara penyitaan tersebut harus ditandatangani oleh panitera atau juru sita atau penggantinya yang melakukan pekerjaan itu dengan saksi-saksinya.

Menurut Surat Edaran Mahkamah Agung Nomor 5 Tahun 1975 butir 1-e, mengingatkan agar lebih dahulu dilakukan penyitaan terhadap barang-barang bergerak, dan baru kemudian bila diperkirakan nilai barang terhadap barang bergerak tidak mencukupi, dilakukan penyitaan terhadap barang tidak bergerak (tetap).

Barang bergerak yang dikenali atau dibebani sita jaminan, harus tetap ada pada pihak yang tersita untuk disimpannya dan dijaga serta dilarang untuk menjual atau mengalihkannya, atau barang bergerak yang disita itu dapat pula disimpan di tempat lain yang patut.

Jika barang yang disita barang yang tidak bergerak maka berita acara penyitaan itu diumumkan kepada khalayak ramai dan bagi yang diperintahkan untuk menyita barang haruslah menyuruh kepada Kepala Desa atau Kampung supaya tentang penyitaan tersebut diketahui oleh orang sebanyak-banyaknya. Pasal 1131 KUH Perdata, mengingatkan agar mengenai barang-barang tidak bergerak atau barang tetap harus dicatat dalam register yang telah disediakan untuk itu di Pengadilan Negeri dan tembusan berita harus disampaikan kepada Kantor Pertanahan atau pejabat yang bertugas dan berwenang membuat akte jual beli, sehingga tidak akan terjadi pemindahtanganan benda-benda yang ada di bawah penyitaan. Setelah semuanya dilakukan, maka terhitung mulai hari berita acara tentang penyitaan itu dilaporkan di Kantor Pertanahan tidaklah boleh bagi pihak tersita untuk memindahkan atau menyewakan barang-barang yang disita tersebut, dan jika ada perjanjian yang bertentangan dengan larangan ini maka tidak dapat dipergunakan untuk melawan orang yang menjalankan penyitaan tersebut.

Dalam hal barang-barang tersebut sudah di sita jaminan, tidak berarti bahwa pihak tersita kehilangan hak miliknya, hak milik tersebut masih ada pada pihak tersita, pihak tersita hanya kehilangan wewenangnya untuk menjual, membebani dengan hak-hak lain dan harus menjaganya supaya tidak rusak.

Dengan demikian barang-barang yang telah disita adalah tidak benar bila diambil dari kekuasaan tersita atau tergugat dan diserahkan kepada si pemohon atau penggugat. Mengenai hal ini diatur pula dalam Surat Edaran Mahkamah Agung Nomor 5 Tahun 1975 butir 1-g yang menyebutkan bahwa agar barang-barang yang disita tidak diserahkan kepada pihak pemohon, karena hal ini menimbulkan kesan seolah-olah sudah pasti digunakan untuk kepentingan pemohon. 
Menurut pasal 725 BRV, sita jaminan dapat dicabut apabila :

a. Debitur membayar sesuatu jumlah berupa jaminan.

b. Jika gugatan ternyata tidak sempurna.

c. Jika sitaan itu nyata-nyata tidak diperlukan.

Kemungkinan lain yang bisa terjadi adalah setelah gugatan perkara pokoknya diperiksa dalam tingkat banding, baru diajukan permohonan sita jaminan. Jika terjadi hal yang demikian, maka permohonan sita jaminan dapat diajukan melalui ketua Pengadilan Negeri, akan tetapi untuk lebih cepatnya permohonan dapat langsung diajukan kepada ketua Pengadilan Tinggi.

Mengingat fungsi dari pada sita jaminan sebagai tindakan yang sifatnya sementara, hanya menjamin hak dan bukan merupakan pokok perkara, maka tidak akan mempengaruhi pemeriksaan pokok perkara yang bersangkutan di tingkat banding.

Surat penetapan penyitaan tersebut dikirim ke Pengadilan Tinggi untuk diperiksa bersama-sama dengan pokok perkara yang bersangkutan. Kalau Pengadilan Tinggi menguatkan putusan Pengadilan Negeri yang mengabulkan gugatan, maka didalam dictum putusan Pengadilan Tinggi ditambahkan bahwa permohonan sita jaminan yang telah dikabulkan oleh Pengadilan Negeri dinyatakan sah dan berharga. Sedang apabila Pengadilan Tinggi membatalkan putusan Pengadilan Negeri, maka didalam putusannya ditambahkan bahwa sita jaminan itu diangkat atau dicabut.

Suatu sita jaminan supaya mempunyai sifat eksekutorial, maka sita jaminan tersebut dinyatakan sah dan berharga dalam keputusan yang telah mempunyai kekuatan hukum yang pasti dan mengikat.

Seperti halnya hakim dalam memutuskan suatu perkara dengan putusan verstek (tanpa hadirnya tergugat), maka disini dapatlah terlihat dengan tidak hadirnya tergugat itu sudah mempunyai itikad yang tidak baik, karena dimungkinkan selama pemeriksaan pokok perkaranya berlangsung, tergugat telah pergi meninggalkan rumahnya untuk tidak memenuhi kewajibannya (sesuai pasal 1131 KUH Perdata).

\section{B. Kendala-Kendala Yang Ditemui Dalam Praktek Berkenaan Pelaksanaan Sita Jaminan Terhadap Keputusan Perkara Perdata}

Dalam kenyataan sehari-hari, tidaklah jarang terjadi bahwa setelah suatu gugatan dimenangkan dan sita jaminan dinyatakan sah dan berharga dalam suatu keputusan yang mempunyai kekuatan hukum yang pasti dan mengikat, ternyata keputusan tersebut tidak dapat dilaksanakan. Dari hasil penelitian diperoleh keterangan bahwa faktor penyebabnya adalah karena barang-barang yang telah disita pada waktu akan dilaksanakan sudah tidak ada lagi atau sudah rusak, atau telah ada perlawanan dari pihak ketiga yang ternyata adalah pemilik sah dari pada barang yang disita atau karena barang yang disita tersebut telah diagunkan di Bank.

Dengan demikian Sita Jaminan yang diharapkan pemohon (penggugat) dapat menjamin terlaksananya keputusan perdata, tidak dapat memenuhi fungsinya sebagai tindakan pendahuluan yang dapat menjamin terlaksananya keputusan tersebut.

Menurut analisis penulis, barangkali hal ini disebabkan karena kurang jelinya aparat pelaksana di satu pihak, baik yang berhubungan dengan syarat-syarat yang telah diberikan oleh undang-undang maupun dalam acara pelaksanaannya, terlalu tergesa-gesa dalam melaksanaan penyitaan tanpa meneliti lebih dulu, apakah barang-barang yang dibebani sita jaminan itu benar-benar milik penggugat sendiri atau milik orang lain. Kadangkala pihak pelaksana tidak memperhatikan, pada saat diadakan penyitaan pendahuluan ada pihak ketiga yang mengajukan keberatannya atas penyitaan yang telah dilakukan. Atau bisa terjadi karena hakim yang memeriksa permohonan sita jaminan kadang-kadang terlalu mengandalkan kepada kebiasaan berdasarkan pengalaman dalam membuat suatu penetapan yang diperintahkan kepada Panitera atau jurusia untuk melaksanakan lagi kepada wakilnya atau penggantinya yang sah, tetapi kurang mau membandingkan pengalamannya dengan meneliti kembali hokum acaranya.

Di samping adanya kesalahan-kesalahan atau kekeliruan-kekeliruan dari pihak pelaksana dalam melakukan peletakan sita jaminan, juga karena adanya pelanggaran dari 
pihak tergugat itu sendiri. Adanya pelanggaran ini disebabkan karena proses pemeriksaan perkara perdata yang memakan waktu lama. Dalam praktek tidaklah dapat disangkal, bahwa sejak suatu perkara didaftarkan di Kepaniteraan Pengadilan Negeri sampai pada pemeriksaan yang pertama kalinya akan memakan waktu yang cukup lama. Pada umumnya waktu tersebut sampai dua bulan, bahkan sampai lebih dari tiga bulan.

Demikian pulauntuk permohonan sita jaminan, sampai diterimanya permohonan dan ditetapkan dalam suatu surat serta dilaksanakannya dengan memerlukan waktu yang cukup lama. Dengan adanya waktu yang cukup lama tersebut, berarti merupakan kesempatan bagi debitur atau tergugat untuk melakukan kecurangan atau pelanggaran, dan juga justru dapat mendorong timbulnya ketidakjujuran dengan cara mengalihkan memindatangankan harta miliknya dalam usaha untuk menghindari tuntutan dari pihak kreditur atau penggugat.

Adanya pelanggaran terhadap barang yang telah di sita jaminankan, berarti barangbarang yang diharapkan menjadi persediaan pemenuhan pelaksanaan putusan tersebut telah hilang. Adanya pelanggaran-pelanggaran ini mengakibatkan tidak terpenuhnya fungsi Sita jaminan sebagai jaminan untuk dapat terlaksananya suatu keputusan perkara perdata dan tidak terjaminnya hak dari pemohon Sita Jaminan, karean kemungkinan untuk dapat terealisasinya keputusan yang memenangkan adalah sangat kecil.

Sejalan dengan adanya suatu norma hukum, agar hukum tersebut dapat ditaati oleh masyarakat khususnya pihak debitur atau tergugat, maka harus disertai dengan sanksi hukum yang lebih sesuai diterapkan terhadap pelanggaran atas barang-barang yang telah di Sita Jaminan, baik yang berupa perbuatan menggelapkan, merusak atau membiarkan barang-barang yang telah di Sita Jaminan menjadi rusak, maka diancam pidana sebagaimana tersebut dalam ketentuan pasal 231 KUHP.

Dari hasil penelitian diperoleh keterangan bahwa dalam melaksanakan peletakan Sita jaminan, aparat pelaksana banyak menemui hambatan-hambatan, yakni karena keadaan sosial ekonomi masyarakat khususnya dari pihak debitur atau tergugat sendiri, yang menyebabkan pelaksanaan dan peletakan Sita Jaminan tidak dapat berjalan dengan sempurna. Selain dari pihak debitur atau tergugat, daripihak Kepala Desa dan dari masyarakat sempat juga dapat menghambat pelaksanaan dan peletakan Sita Jaminan.

Dari pihak tergugat, yang selalu berusaha untuk mempertahankan hak miliknya, dengan berbagai macam alasan tergugat berusaha menghindari penyitaan atas berangbarangnya dengan mengatakan bahwa barang tersebut bukan miliknya, tetapi milik orang lain dititipkan kepadanya.

Kadangkala petugas datang untuk melaksanakan penyitaan, tergugat sudah tidak ditempat lagi atau meninggalkan rumahnya untuk menghidari penyitaan tersebut. Dan yang lebih berat lagi adalah melakukan penyitaan yang obyeknya di Pedesaan, yang sebagaian besar masyarakatnya masih buta huruf, ia tidak mau tahu apa itu norma dan apa itu sanksi, sesuatu yang seharusnya tidak boleh dilakukan, masih juga dilakukan.

Di samping itu, adanya kurang pengertian dari pihak Kepala Desa, bahkan Kepala desa tersebut enggan untuk mencatat atau menerima laporan dari jurusita tentang penyitaan yang telah dilakukan, apalagi untuk mengumumkannya.

Penyitaan yang dilakukan di Pedesaan lebih berat hambatannya jika dibandingkan dengan penyitaan yang dilakukan di Perkotaan, karena di Pedesaan pada umumnya sifat kekeluargaannya masih kuat, yang secara otomatis mereka akan berpihak kepada si tersita atau penggugat, kadang mereka datang ke Pengadilan, dengan mengatakan bahwa barang yang disita adalah miliknya, tetapi setelah diselidiki ternyata tidak ada hubungan sama sekali dengan barang yang disita.

\section{Penutup}

\section{A. Kesimpulan}

1. Jika permohonan Sita Jaminan diterima, maka hakim yang memeriksa pokok perkaranya akan mengeluarkan surat penetapan Jaminan, dan memerintahkan kepada juru sita atau juru sita pengganti untuk melaksanakannya sehingga diharapkan dapat 
mengakibatkan hak dari pemohon atau penggugat dapat terjamin untuk terlaksananya keputusan tersebut apabila kelak gugatannya dikabulkan atau dimenangkan.

2. Kendala-kendala yang ditemui dalam praktek berkenaan pelaksanaan Sita Jaminan adalah disebabkan karena barang-barang yang telah disita pada waktu akan dilaksanakan sudah tidak ada lagi atau sudah rusak, atau telah ada perlawanan dari pihak ketiga yang ternyata adalah pemilik sah dari pada barang yang disita atau karena barang yang disita tersebut telah diagunkan di Bank. Kemudian dalam melaksanakan peletakan Sita Jaminan, aparat pelaksanan banyak menemui hambatan-hambatan, yakni karena keadaan sosial ekonomi masyarakat khususnya dari pihak debitur atau tergugat sendiri, yang menyebabkan pelaksanaan dan peletakan Sita Jaminan tidak dapat berjalan dengan sempurna. Selain dari pihak debitur atau tergugat, dari pihak Kepala Desa dan dari masyarakat setempat juga dapat menghambat pelaksanaan dan peletakan Jaminan.

Dari pihak tergugat, yang selalu berusaha untuk mempertahankan hak miliknya, dengan berbagai macam alasan tergugat berusaha menghindari penyitaan atas barangbarangnya dengan mengatakan bahwa barang tersebut bukan miliknya, tetapi milik orang lain yang dititikan kepadanya. Kadangkala petugas datang untuk melaksanakan penyitaan, tergugat sudah tidak di tempat lagi atau meninggalkan rumaknya untuk menghindari penyitaan tersebut. Dan yang lebih berat lagi adalah melakukan penyitaan yang obyeknya di Pedesaan, yang sebagaian besar masyarakatnya masih buta huruf, ia tidak mau apa itu norma dan apa itu sanksi, sesuatu yang seharusnya tidak boleh dilakukan, masih dilakukan juga, misalnya begitu petugas datang ia sudah menyambut dengan celuritnya dan mengancam petugas, serta akan melukan kekerasan jika penyitaan dilaksanakan.

\section{A. Saran-Saran}

1. Agar supaya fungsi Sita Jaminan dapat sesuai dengan tujuannya, maka diperlukan penyempurnaan pelaksanaannya yang mungkin dapat menunjang bagi penyelenggaraan peradilan ssesuai dengan apa yang dicita-citakan, maka guna menjamin adanya kepastian hukum akan lebi baik jika tentang perlawanan pihak ketiga terhadap Sita Jaminan diatur di dalam undang-undang hukum acara perdata nasional yang akan datang, karena dalam praktek sering dilakukan atau terjadi dengan berpedoman pada aturan yang terdapat dalam Rv. Di samping itu, hendaknya ditentukan agar ketua sidang atau hakim yang memeriksa perkara tersebut, dengan cermat mengawasi pelaksanaan Sita Jaminanagar pencari keadilan tidak dirugikan oleh tindakan-tinadaka yang ceroboh karena Sita Jaminan merupakan tindak pendahuluan untuk sita eksekutorial, maka harus pula dipikirkan apakah barang-barang yang tersebut sejak dilakukan Sita Jaminan dilarang untuk disita, dan harus pula diteliti betul apakah barang-barang tersebut betulbetul milik tergugat atau milik orang lain, sehingga tidak akan meninmbulkan verzet atau perlawanan.

2. Perlunya dilakukan penyuluhan hukum kepada masyarakat terkait dengan masalah Sita Jaminan ini, agar dalam pelaksanaan peletakan Sita Jaminan nantinya berjalan dengan sempurna, tanpa adanya kendala-kendala yang ditemui dalam prakteknya dan perlu kiranya meningkatkan kerjasama yang baik antara pihak pelaksana dengan pihak pemohon atau penggugat, tergugat, Kepala Desa serta masyarakat setempat.

\section{DAFTAR PUSTAKA}

Amin, SM, 1981, Hukum Acara Pengadilan Negeri, Penerbit Pradya Paramita, Jakarta.

Afandi, Ateng dan Wahyu Afandi, 1983, Tentang Melaksanakan Putusan Hakim Perdata, Penerbit Alumni, Bandung.

Afandi, Wahyu, 1983, Hukum dan Hukum dalam Praktek, Penerbit Alumni, Bandung.

Bakri, Muhammad, 1995, Pengantar hukum Indonesia, Penerbit IKIP Malang. 
Hamzah, Andi, 1985, Pengantar Hukum Acara Pidana Indonesia,Penerbit Ghalia Indonesia, Jakarta.

Harahap, Yahya, 1993, Kedudukan Kewenangan Acara Peradilan Agama, Penerbit Pustaka Kartini, Jakarta.

Kansil, CST, 1979, Pengantar Ilmu Hukum dan Tata Hukum Indonesia, Penerbit Balai Pustaka, Jakarta.

Loudoe, John Z., 1982, Beberapa Aspek Hukum Materiil dan Hukum Acara dalam Praktek, Penerbit Alumni, Bandung.

Mertokusumo, Sudikno, 1988, Hukum Acara Perdata Indonesia, Penerbit Liberty, Yogyakarta.

Muhammad, Abdul Kadir, 1982, Hukum Acara Perdata Indonesia,Penerbit Alumni, Bandung.

Marzuki, 1986, Metodologi Riset, Badan Penerbitan UII, Yogyakarta.

Purbacaraka, Purnadi dan SoerjonoSoekamto, 1976, Perihal Kaidah Hukum, Penerbit Alum ${ }^{\text {: }}$ Bandung.

Prodjodikoro, Wiryono, 1982, Hukum Acara Perdata Indonesia, Penerbit Sumur, Bandung.

Raharjo, satjipto, 1979, Hukum dan Perubahan Sosial, Penerbit Alumni, Bandung. , 1982, Ilmu Hukum, Penerbit Alumni, Bandung.

Saleh, K. Wantjik, 1977, Hukum Acara Perdata, Penerbit Ghalia Indonesia, Jakarta.

Soetantio, Retnowulan dan Iskandar Oeripkartawinata, 1986, Hukum Acara dalam Teori dan Preaktek, Penerbit Alumni, Bandung.

Supomo, 1982, Hukum Acara Pengadilan Negeri, Penerbit Pradnya Paramita, Jakarta.

Soesilo. R, 1979, RIB/HIR dengan Penjelasannya, Penerbit Politia, Bogor.

Subekti R dan R Tjitrosudibio, 2000, Kitab Undang-undang Hukum Pidana, Penerbit Pradnya Paramita, Jakarta.

Sugandhi R, 1980, KUHP dan Penjelasannya, Penerbit Usaha Nasional, Surabaya.

Soekamto, Soerjono dan Sri Mamudji, 1995, Penelitian Hukum Normatif, Penerbit Rajawali Pers, Jakarta.

Soemitro, Ronny Hanitijo, 1994, Metode Penelitian Hukum dan Jurumetri, Penerbit Ghalia Indonesia, Jakarta.

Tresna, 1980, Komentar HIR, Penerbit Pradnya Paramita, Jakarta. 